\title{
Does clinical mastitis in the first 100 days of lactation 1 predict increased mastitis occurrence and shorter herd life in dairy cows?
}

\author{
J. A. Hertl, ${ }^{* 1}$ Y. H. Schukken, ${ }^{\star} † \ddagger$ L. W. Tauer,§ F. L. Welcome,\# and Y. T. Gröhn* \\ *Section of Epidemiology, Department of Population Medicine and Diagnostic Sciences, College of Veterinary Medicine, Cornell University, \\ Ithaca, NY 14853 \\ †GD Animal Health, Deventer 7418EZ, the Netherlands \\ ‡Department of Animal Sciences, Wageningen University, Wageningen 6708PB, the Netherlands \\ $\S$ Charles H. Dyson School of Applied Economics and Management, Cornell SC Johnson College of Business, and \\ \#Quality Milk Production Services, Department of Population Medicine and Diagnostic Sciences, College of Veterinary Medicine, \\ Cornell University, Ithaca, NY 14853
}

\section{ABSTRACT}

The objectives of this study were to estimate the direct effects of clinical mastitis (CM) occurring in early productive life (defined as the first $100 \mathrm{~d}$ of the first lactation) of Holstein dairy cows on the future rate of $\mathrm{CM}$ occurrence and on the length of total productive lifetime. Information on CM cases and other data occurring in 55,144 lactations in 24,831 cows in 5 New York State Holstein herds was collected from January 2004 until February 2014. For the first objective, a generalized linear mixed model with a Poisson distribution was used to study the effects of CM cases occurring in the first $100 \mathrm{~d}$ of a cow's first lactation, as well as farm indicator and number of days in the cow's lifetime, on the future lifetime rate of CM. Only cows that had completed their productive life [i.e., all had been culled (or sold) or had died; $\mathrm{n}=14,440 \mathrm{cows}]$ were included in this analysis. For the second objective, a Cox proportional hazards model was used to study the effects of CM cases occurring in the first $100 \mathrm{~d}$ of a cow's first lactation on the length of total productive lifetime. The model was stratified by farm. All 24,831 cows were included in this analysis with right censoring. Cows experienced between 0 and $4 \mathrm{CM}$ cases in the first 100 $\mathrm{d}$ of lactation 1. Over their lifetime, cows experienced between 0 and $25 \mathrm{CM}$ cases. During the study period, $10 \%$ of all cows died and nearly half of all cows were culled. The average length of productive life, including censored observations, was $2.0 \mathrm{yr}$ after first calving. Compared with cows having no $\mathrm{CM}$ cases in the first $100 \mathrm{~d}$ of lactation 1 , cows with $1 \mathrm{CM}$ case in that time period had a 1.5 times higher rate of total number of $\mathrm{CM}$ cases over their lifetime. Cows with 2 (or 3 or more)

Received January 19, 2017.

Accepted November 7, 2017.

${ }^{1}$ Corresponding author: jah12@cornell.edu
$\mathrm{CM}$ cases in the first $100 \mathrm{~d}$ of lactation 1 had a 1.7 times (or 2.6 times) higher rate of total number of CM cases over their lifetime. For each additional CM case occurring in the first $100 \mathrm{~d}$ of lactation 1, the hazard rate of culling increased by $34 \%$. Given economic conditions for preferentially culling mastitic cows, the study findings may help farmers make optimal decisions with regard to culling of such cows.

Key words: mastitis, herd life, generalized linear mixed models, survival analysis

\section{INTRODUCTION}

Clinical mastitis (CM) is an important disease in the dairy industry worldwide. It may cause discomfort to the cow (Fitzpatrick et al., 2013; Fogsgaard et al., 2015) and is costly to the farmer in multiple ways. It can occur multiple times in a lactation and may result in lower milk production (Houben et al., 1993; Hertl et al., 2014a), with lower reproductive performance (Herath et al., 2009; Hertl et al., 2014b), increased veterinary costs (Kossaibati and Esslemont, 1997; van Soest et al., 2016), and increased mortality and culling (Thomsen et al., 2004; Cha et al., 2013). Clinical mastitis occurring at any time in productive life is detrimental, but may be particularly so if it occurs early in productive life. Our interest in the present study was to evaluate whether $\mathrm{CM}$ cases occurring in early productive life, which we defined as the first $100 \mathrm{~d}$ of a cow's first lactation, would be predictive for future cases and potentially for the rate of survival in the herd.

Houben et al. (1993) estimated the probability of CM cases occurring in the following month of Dutch Black and White cows' current lactation as a function of several factors, including number of CM cases occurring in the previous lactation, number of CM cases occurring in the previous months of the current lactation, and whether or not CM occurred in the current month of 
the current lactation. Having CM in any of these 3 time periods increased a cow's probability of having CM in the next month of her lactation.

Faye et al. (1996) developed a method to identify disease patterns associated with cows' life spans using data collected over 10 to $20 \mathrm{yr}$ in 3 French farms. They found that a very high incidence of mastitis was associated with shorter life spans, although the timing of mastitis cases was not detailed. In contrast, cows with both mastitis and milk fever were more likely to have longer life spans.

Using survival analysis, Neerhof et al. (2000) compared several models estimating the effect of mastitis on risk of culling. These models differed in how long an episode of mastitis was assumed to affect the risk of culling. The highest risk occurred when the effect of mastitis was assumed to persist until the end of lactation, where the risk of culling for a mastitic cow was 1.7 times higher than that of a healthy cow. Their other models assumed the effect of mastitis to last only 10, 100, 200, 400, and $800 \mathrm{~d}$ after occurrence; the risk ratios varied from 1.2 for the shortest time period (10 d) to 1.6 (for $400 \mathrm{~d}$ ).

Although some studies have investigated the recurrence of CM, few studies have researched the effects of CM occurring early in productive life on later likelihood of CM occurrence or on total length of productive lifetime (Bar et al., 2008a), which were motivations for the current study. In the Netherlands, Barkema et al. (1998) found that 30\% of CM cases in first-lactation cows occurred in the first 14 DIM; similar findings were reported in Canada by Olde Riekerink et al. (2008). In first-lactation Iranian Holsteins, Moosavi et al. (2014) found that although more CM cases occurred in the first 74 DIM of lactation than later on, the duration of CM was shorter when it occurred during this time period. Those authors also found that early occurrence of $\mathrm{CM}$ in lactation 1 was more likely in winter and spring, possibly due to environmental conditions favoring pathogen growth.

Heravi Moussavi et al. (2012) found that CM occurring between first calving and conception tended to shorten productive life in Holsteins in Iran. The sooner the first mastitis case occurred after calving, the shorter the cow's productive life. Furthermore, the more mastitis cases a cow had, the shorter her productive life. Similarly, among French Holstein cows diagnosed with mastitis in the first $45 \mathrm{~d}$ of lactation 1, $81 \%$ were still alive at the end of lactation 2 (Beaudeau et al., 1995); their median lifetime was $13 \mathrm{~d}$ less than cows not having mastitis in the first $45 \mathrm{~d}$ of lactation 1.

Although the risk of repeated cases of mastitis in the same lactation has been studied in much detail (Barkema et al., 1998; Piepers et al., 2010), the car- ryover of risk from one lactation to the next has not been studied in detail. Furthermore, the specific risk of mastitis in early productive life on subsequent cases throughout a cow's full lifetime has not been studied in recent literature. Such studies are inherently difficult, as long-term follow-up of a large number of animals is necessary to obtain reliable results. The value of early lifetime mastitis experience as a predictor of future cases lies in obtaining an early indication of the cow's ability to remain healthy. Such information may be valuable with regard to management of high-risk cows, eventual culling or keeping decisions that are being made by the dairy producer, and a general interest in the pathobiology of repeated cases of CM in dairy cows. We have repeatedly shown that, unlike many other infectious diseases, a case of CM does not protect against a subsequent case in the same lactation (Schukken et al., 2009; Cha et al., 2016). A further understanding on the risk of repeated cases of CM throughout the cow's productive life will be of value to better study the mechanisms behind this somewhat unexpected finding from observational studies.

In the current study, the focus was on the effects of CM occurring early in a cow's productive life, namely in the first $100 \mathrm{~d}$ of a cow's first lactation, on future CM occurrence and on length of total productive life. Productive lifetime (lifetime days) was defined as the number of days between lactation 1 calving date and culling or death either in lactation 1 or a subsequent lactation or, if still alive, end-of-study date (February $4,2014)$. The objectives of our study were to examine the effects of $\mathrm{CM}$ cases occurring in the first $100 \mathrm{~d}$ in a cow's first lactation on (1) future rate of lifetime CM and (2) total productive lifetime in New York Holstein cows.

\section{MATERIALS AND METHODS}

\section{Herd Descriptions}

Five Holstein herds, 3 from central New York State, 1 from northern New York, and 1 from western New York, participated in the study. Average herd size was approximately 1,260 cows. These were well-managed, high-producing farms, with 305-d rolling herd average milk production ranging from 11,260 to $13,123 \mathrm{~kg} / \mathrm{cow}$ per year. Monthly mean SCC ranged from 137,000 to 262,000 cells $/ \mathrm{mL}$. Cows were housed in freestalls in covered barns and were managed in groups according to lactation month, production, and reproduction status. They were fed a balanced TMR and were milked 3 times a day. DairyComp305 herd management software (Valley Agricultural Software, Tulare, CA) was used to record information on calving, milk production, milk 
conductivity, parity, reproductive performance, diseases, drying off, and culling or death.

Information was available on recorded $\mathrm{CM}$ cases from January 2004 through February 2014 in 55,144 lactations from 24,831 cows. All cows in the study were followed from lactation 1 calving date through the final available day of that or subsequent lactations. Cows exited the study through either culling, death, or when they remained in the herd at the end-of-study date, February 4, 2014.

\section{Cow Selection Criteria}

All lactating cows in the 5 herds that had complete lifetime data beginning with calving date of lactation 1 and continuing through all subsequent lactations until culling or death or end of study were eligible for inclusion in the study. The earliest eligible calving date was January 4, 2004. Cows that were missing data on some lactations (e.g., had information on lactations 2 and 3 but had no information on lactation 1 , perhaps because this lactation began before the earliest eligible calving date) were not eligible for inclusion. The data set used in the study contained a total of 24,831 eligible cows.

For objective 1 (estimation of effects of CM cases occurring in the first $100 \mathrm{~d}$ in a cow's first lactation on future rate of lifetime $\mathrm{CM}$ ), a subset of these data was used: only cows that had completed their productive lifetime (i.e., had been culled or died; $\mathrm{n}=14,440$ cows) were included in that analysis.

For objective 2 (estimation of effects of $\mathrm{CM}$ cases occurring in the first $100 \mathrm{~d}$ in a cow's first lactation on total productive lifetime), the full data set of 24,831 cows was used: both cows that had been culled or had died during the study period and those still alive at end of study (4 February 2014). Cows still alive on the end-of-study date were right-censored [i.e., the event of interest (culling or death) had not occurred by the end of the observation period]. For both objectives, the individual cow was the unit of analysis.

\section{Case Definition}

Milkers identified the majority of clinical cases upon routine examination of fore-stripped milk immediately before milking. These cases frequently were manifested as a warm, swollen udder, or changes in milk consistency. Some cows, however, were observed to have a sudden decline in milk yield $(<70 \%$ of the average of the previous $10 \mathrm{~d}$ ) or increase in milk conductivity ( $>115 \%$ of the average of the previous $10 \mathrm{~d}$ ). The parlor manager or hospital pen manager segregated these cows for additional evaluation to determine the cause of the milk deviation or increased milk conductivity. Alone, milk yield deviations or increases in milk conductivity would not qualify as a diagnosis of CM. These cows were therefore examined further to determine the cause of the deviation, and a diagnosis of $\mathrm{CM}$ required the identification of abnormal milk, or a painful or swollen quarter; in some cases CM was observed. Clinical mastitis cases were characterized by the demonstrated clinical signs, including (1) abnormal appearance of milk (watery, flakes, fibrin clots, and so on; mild); (2) abnormal appearance of milk PLUS swollen or painful quarter (moderate); and (3) abnormal appearance of milk plus swollen or painful quarter and a cow demonstrating systemic signs of illness (fever, decreased appetite, dehydration, and so on; severe). Treatment and management protocols for CM cows were assigned to individual cows based on clinical signs category and pathogen identification. Cows demonstrating mild or moderate signs were typically treated with intramammary medication according to the identified pathogen protocol. Cows with severe signs received systemic treatment, which typically included rehydration, systemic antibiotics, pain relief, and other supportive therapies as needed.

Milk samples from cows with CM signs were sent to the Quality Milk Production Services laboratories in Ithaca, Canton, or Geneseo, New York, for culturing. The microbiological diagnosis procedures are described in detail in Gröhn et al. (2004).

If a second CM case occurred in the same quarter within $5 \mathrm{~d}$ after a first case (with either the same or a different pathogen isolated) or occurred within $14 \mathrm{~d}$ with the same pathogen isolated from both cases, it was considered to be the same CM case. Any case occurring more than $14 \mathrm{~d}$ after the previous case had been diagnosed, regardless of the pathogen isolated, was considered to be a new CM case (Barkema et al., 1998).

We also performed a sensitivity analysis by using a 28-d period rather than $14 \mathrm{~d}$, as in the main analysis. That is, if a second CM case occurred in the same quarter within $28 \mathrm{~d}$ with the same pathogen isolated from both cases, it was considered to be the same case. The other parts of the case definition (concerning cases occurring within $5 \mathrm{~d}$ or after $28 \mathrm{~d}$ ) remained the same.

\section{Statistical Analysis}

Objective 1. The rate of CM in 100-d intervals over productive lifetime was calculated. The number of $\mathrm{CM}$ cases occurring in each 100-d interval was summed and then divided by the number of cows still alive (including both lactating and dry cows) in that interval. It should be noted that the true incidence rate was slightly over- 
estimated, as cow-days for cows that were culled or died within the 100-d interval were disregarded. Necessarily, the number of cows was lower in each successive interval; all 24,831 cows were represented in the first interval of 0 to $100 \mathrm{~d}$ of productive lifetime, only 22,836 cows were represented in the second interval of 101 to $200 \mathrm{~d}$ of productive lifetime (because 1,995 had been culled, died, or been censored due to end of study before $101 \mathrm{~d}$ ), and so on, until the final interval of 3,601 to $3,700 \mathrm{~d}$ of productive lifetime, in which only 2 cows were represented. For example, in the first interval, 0 to $100 \mathrm{~d}$, we had 2,316 CM cases among all 24,831 cows that had each 100 cow-days at risk; thus, the incidence rate was $2,316 /(24,831 \times 100)=0.00093$ cases per cowday at risk. In the second interval, 101 to $200 \mathrm{~d}$, we had $1,859 \mathrm{CM}$ cases in the 22,836 cows with 100 cow-days at risk remaining in the risk set $(1,995$ had exited the study); thus, the incidence rate was $1,859 /(22,836 \times$ $100)=0.00081$ cases per cow-day at risk. These values were then multiplied by 10,000 so as to report the rates per 10,000 cow-days at risk.

The 95\% confidence intervals for the above rates were calculated in each 100-d interval according to the formula (Pennsylvania Department of Health, 2017)

$$
\begin{gathered}
\text { Lower limit }=(100 / \mathrm{n}) \times\{\mathrm{d}-[1.96 \times \operatorname{sqrt}(\mathrm{d})]\} \text {, and } \\
\text { Upper limit }=(100 / \mathrm{n}) \times\{\mathrm{d}+[1.96 \times \operatorname{sqrt}(\mathrm{d})]\},
\end{gathered}
$$

where $\mathrm{n}=$ number of cows in the interval; $\mathrm{d}=$ number of $\mathrm{CM}$ cases in the interval; and sqrt $=$ square root function.

A generalized linear mixed model with a Poisson distribution (PROC GLIMMIX in SAS, version 9.2; SAS Institute Inc., Cary, NC) was used to study the effects of CM cases occurring in the first $100 \mathrm{~d}$ of a cow's first lactation on the future lifetime number of $\mathrm{CM}$ cases. As stated, only cows that had been culled or had died during the study period $(\mathrm{n}=14,440)$ were included in this analysis. Table 1 shows some key variables for some example cows used in the analysis for objective 1 .

In the Poisson regression, the offset variable was $\log$ (lifetime days), where lifetime days, as mentioned above, was the number of days from lactation 1 calving date until culling or death date or end-of-study-date (February 4, 2014). Lifetime days included dry periods between lactations; cows in the 5 study herds had a mean dry period of $61 \mathrm{~d}$ and a median dry period length of $55 \mathrm{~d}$. The offset is an adjustment term, used to account for the fact that cows were followed for differing lengths of time.

The outcome variable was the total number of $\mathrm{CM}$ cases in a cow's productive lifetime. This measure excluded cases that occurred in the first $100 \mathrm{~d}$ of lactation 1. The total number of days at risk of CM included both lactating and dry days. Independent variables were farm $(1,2,3,4,5)$, total number of $\mathrm{CM}$ cases in the first $100 \mathrm{~d}$ of lactation $1(0,1,2,3,4)$, a binary variable indicating whether or not a cow had any $\mathrm{CM}$ cases in the first $100 \mathrm{~d}$ of their first lactation (cases01), lifetime days, and the interaction between cases01 and lifetime days; all were modeled as fixed effects. Lifetime days was included to evaluate whether the rate of mastitis (number of cases/days at risk) was related to the total days the cow was in the herd; the quadratic term (lifetime days squared) was also included to account for the fact that the rate of $\mathrm{CM}$ might be lower in older cows. The interaction (lifetime days $\times$ cases01) served as an adjustment for the shape of the CM rate curve based upon the lifetime of cows experiencing versus not experiencing $\mathrm{CM}$ in the first $100 \mathrm{~d}$ of the first lactation. Because the rate of mastitis was being modeled, there was no bias with regard to the length of a cow's lifetime and the incidence of mastitis. This would have been an issue if instead the number of cases of mastitis were modeled.

The following generalized linear mixed model was fitted:

Table 1. Data layout for 7 example cows to study the effect of clinical mastitis (CM) cases occurring in the first $100 \mathrm{~d}$ of lactation 1 and other factors on future rate of lifetime CM in 14,440 cows that were culled or died in 5 New York State farms, followed from January 2004 until February 2014

\begin{tabular}{llccc}
\hline Cow ID & $\begin{array}{l}\text { Cow experienced CM in first } \\
\text { 100 d of lactation 1 }\end{array}$ & $\begin{array}{c}\text { Number of CM cases in } \\
\text { first 100 d of lactation 1 }\end{array}$ & $\begin{array}{c}\text { Length of productive } \\
\text { lifetime }^{1}(\mathrm{~d})\end{array}$ & $\begin{array}{c}\text { Total number of CM } \\
\text { cases in later lifetime }^{2}\end{array}$ \\
\hline 1 & No & 0 & 412 & 0 \\
2 & No & 0 & 371 & 4 \\
3 & Yes & 1 & 534 & 1 \\
4 & Yes & 1 & 372 & 2 \\
5 & Yes & 2 & 613 & 0 \\
6 & Yes & 2 & 1,289 & 5 \\
7 & Yes & 2 & & \\
\hline
\end{tabular}

${ }^{1}$ Productive lifetime was defined as number of days between lactation 1 calving date and culling or death either in lactation 1 or a subsequent lactation or, if still alive, end-of-study date (February 4, 2014).

${ }^{2}$ Excluding cases occurring in first $100 \mathrm{~d}$ of lactation 1. 
Table 2. Data layout for 9 example cows to study the effect of clinical mastitis (CM) on length of productive lifetime $^{1}$ in 24,831 cows in 5 New York State farms, followed from January 2004 until February 2014

\begin{tabular}{lccc}
\hline Cow ID & $\begin{array}{c}\text { Number of CM cases in first } \\
\text { 100 d of lactation } 1\end{array}$ & $\begin{array}{c}\text { Length of productive } \\
\text { lifetime }(\mathrm{d})\end{array}$ & Censor $^{3}$ \\
\hline 1 & 0 & 412 & 1 \\
8 & 0 & 117 & 0 \\
9 & 0 & 1,092 & 1 \\
10 & 0 & 554 & 0 \\
11 & 2 & 102 & 1 \\
12 & 1 & 719 & 1 \\
13 & 1 & 273 & 1 \\
15 & 2 & 481 & 0 \\
\hline
\end{tabular}

${ }^{1}$ Productive lifetime was defined as number of days between lactation 1 calving date and culling or death either in lactation 1 or a subsequent lactation or, if still alive, end-of-study date (February 4, 2014).

${ }^{2}$ Cow ID numbers 2 to 7 were skipped to avoid confusion with cows listed in Table 1 , which are all different cows from those listed in Table 2, except for cow 1, which is the same cow, in both Tables 1 and 2.

${ }^{3}$ Censor: $0=$ still in herd at end of study; 1 = culled or died during the term of the study.

$\log ($ cases $)=\log ($ lifetime days $)[$ offset $]+$ number

of CM cases in first $100 \mathrm{~d}$ of lactation $1+$ lifetime

$$
\begin{gathered}
\text { days }+ \text { lifetime days }{ }^{2}+\text { cases } 01+\text { lifetime days } \\
\times \text { cases } 01+\text { farm }+e,
\end{gathered}
$$

where the outcome, cases, was the number of CM cases in a cow's lifetime (excluding cases occurring in the first $100 \mathrm{~d}$ of lactation 1) and all other terms are as described above. The variable $\log$ (lifetime days) served as the offset variable (essentially the denominator of the rate equation), accounting for the fact that cows were followed for different lengths of time, and $e$ was the error term.

The same model as above was fitted, but instead using a different case definition for new CM cases. Here, a 28 -d period, rather than $14 \mathrm{~d}$ as in the main analysis, was assessed. It was also of interest to assess the effects of $\mathrm{CM}$ cases only in cows that calved for the first time early in the study period, as they had the greatest opportunity to experience events and had a full life opportunity to be represented in the analyses. Accordingly, a model including only cows that had calved between January 4, 2004, and December 31, 2006, was fitted.

Goodness of fit of the models was assessed using the Pearson Chi-Square/DF statistic. Overdispersion, which occurs when the variance of the response is greater than the mean of the response, was assessed by fitting the models again, but including the 'random _residual_' statement of PROC GLIMMIX to account for overdispersion.

Objective 2. Survival analysis, with a Cox proportional hazards model (PROC PHREG in SAS, version 9.2), was used to study the effects of CM cases occurring in the first $100 \mathrm{~d}$ of lactation 1 on total productive lifetime. As stated above, the full data set of 24,831 cows was used in this analysis. Table 2 shows some of the variables for several cows in the data set used in objective 2 .

The outcome was the hazard rate of culling. The predictor was total number of CM cases in the first $100 \mathrm{~d}$ of lactation 1. Stratified analysis was done by farm, so that each farm would have its own baseline hazard of culling or death. The model fitted was

$$
\begin{aligned}
& \text { Lifetime days } \times \text { censor }(0)=\text { Number of } \mathrm{CM} \\
& \text { cases in first } 100 \mathrm{~d} \text { of lactation } 1+e
\end{aligned}
$$

where lifetime days $=$ number of days from lactation 1 calving date until culling, death, or end-of-study date; censor $=0$ indicated that the cow was still alive at the end of the study, and censor $=1$ indicated that the cow was culled or had died; and $e$ was the error term.

A model using a different case definition for new CM cases (i.e., a 28-d period, rather than $14 \mathrm{~d}$ as in the main analysis) was also fitted. Two other models, including only cows that calved for the first time between January 4, 2004, and December 31, 2006, and utilizing either the 14- or 28-d period definition for new CM cases, were also fitted.

Goodness of fit of the models was assessed with the likelihood ratio test. The -2 Log-likelihood values of the models with and without covariates were compared.

We used SAS (version 9.2) PROC LIFETEST with the LIFETABLE method to estimate survival proportions and life expectancy. Two separate analyses, stratified by either number of $\mathrm{CM}$ cases occurring in the first $100 \mathrm{~d}$ of lactation 1 or by calendar year of commencement of first lactation, were conducted. The estimates from the life tables were used to create graphs of survival. 
Table 3. Clinical mastitis (CM) cases occurring in first $100 \mathrm{~d}$ of lactation 1, among 14,440 cows in 5 New York farms that were culled or died (either in lactation 1 or a subsequent lactation), and in all 24,831 cows (including the aforementioned 14,440 culled or dead cows, plus 10,391 cows still alive on February 4, 2014) between January 2004 and February 2014

\begin{tabular}{lrr}
\hline $\begin{array}{l}\text { Number of CM cases in first } \\
100 \text { d of lactation } 1\end{array}$ & $\begin{array}{r}\text { Number (\%) of cows of 14,440 } \\
\text { culled or dead cows }\end{array}$ & $\begin{array}{c}\text { Number (\%) of cows of 24,831 } \\
\text { cows (culled or dead and alive) }\end{array}$ \\
\hline 0 & $13,023(90.2)$ & $22,788(91.8)$ \\
1 & $1,234(8.6)$ & $1,801(7.3)$ \\
2 & $156(1.1)$ & $203(0.8)$ \\
3 & $21(0.2)$ & $31(0.1)$ \\
4 & $6(0.04)$ & $8(0.03)$ \\
\hline
\end{tabular}

\section{RESULTS}

\section{Objective 1}

Descriptive Findings. Table 3 shows the number and proportion of cows having $0,1,2,3$, or $4 \mathrm{CM}$ cases in the first $100 \mathrm{~d}$ of lactation 1 . Approximately $10 \%$ of cows had at least $1 \mathrm{CM}$ case during this time period. Over their entire lifetime, cows that were culled or died $(\mathrm{n}=14,440)$ experienced between 0 and $23 \mathrm{CM}$ cases.

During the study period (January 2004 through February 2014), approximately $10 \%$ of cows died and nearly half were culled. The average length of productive life was approximately $2 \mathrm{yr}$ after first calving including in cows that were censored, but was as long as 7 yr among cows that died and over 9 yr among cows that were culled.

Figure 1 shows the distribution of length of productive lifetime among cows that were culled or died; all cows in Figure 1 calved for the first time between January 4, 2004, and December 31, 2006. A large number of deaths occurred soon after calving in the first lactation and again around the beginning of the second lactation. Among cows that were culled, the largest number were culled between approximately 600 and 1,000 d of productive lifetime.

Figure 2 shows the rate of $\mathrm{CM}$ (number of $\mathrm{CM}$ cases per 10,000 cow-days at risk) by day of productive lifetime in 100-d blocks. Among first-lactation cows (0-400 d of productive lifetime), the rate varied from 6 to $10 \mathrm{CM}$ cases per 10,000 cow-days. The rate was highest in cows between approximately 500 and 1,500 $\mathrm{d}$ of productive lifetime (ranging from 12 to $18 \mathrm{CM}$ cases per 10,000 cow-days); these were cows that were generally in their second through fourth lactations. The rate dropped among older cows, although these latter estimates were based on only a small number of cows.

Effects of Early CM Cases on Future Lifetime Rate of $\boldsymbol{C M}$. Table 4 presents results from the model (original model) estimating the effects of various factors on rate of $\mathrm{CM}$ occurrence in a cow's lifetime. We also included the quadratic term (lifetime days squared), to account for the fact that the lifetime rate of $\mathrm{CM}$ might be lower in very old cows, as many have survived to that point in a healthy (i.e., non-CM) state. Some differences among farms were evident. The main factor of interest in this study, number of CM cases in a cow's early productive life, had a large effect on future rate of $\mathrm{CM}$ occurrence. Compared with cows having no $\mathrm{CM}$ cases in the first $100 \mathrm{~d}$ of lactation 1 , cows with $1 \mathrm{CM}$ case in that time period had a 1.5 times higher rate of total number of CM cases over their lifetime (rate ratio; Table 4). Cows with $2 \mathrm{CM}$ cases in the first 100 d of lactation 1 had a 1.7 times higher rate of total number of $\mathrm{CM}$ cases over their lifetime than did cows with no CM cases in early productive life. Cows with 3 or more CM cases in early productive life had a 2.6 times higher rate of total number of $\mathrm{CM}$ cases over their lifetime. The longer a cow lived, the higher was her rate of lifetime $\mathrm{CM}$ occurrence; for each additional day of herd life, the rate of $\mathrm{CM}$ occurrence increased by $\exp (0.000487-0.000000169)=1.00049$. Thus, if a cow lived for an extra 6 mo (i.e., $180 \mathrm{~d}$ ) and had experienced $\mathrm{CM}$ in the first $100 \mathrm{~d}$ of lactation 1 , her lifetime rate of contracting CM cases would increase by a multiplication factor defined as $\exp (180 \times 0.000487$ $-180 \times 180 \times 0.000000169-0.000111)=1.086$. The negative estimate for the interaction term [(number of days in lifetime $) \times($ did/did not have CM in first $100 \mathrm{~d}$ of lactation 1)] indicates that the increase in the base lifetime rate of CM is a bit less steep for cows that had a CM case in early productive life. Thus, the lifetime rate is higher for each additional case of early-life CM, but the rate of increase in the lifetime rate over time is slightly less steep $(0.000377=0.000487-0.00011$ vs. 0.000487).

The rate ratios for the effects of number of $\mathrm{CM}$ cases in the first $100 \mathrm{~d}$ of lactation 1 on the rate of total number of $\mathrm{CM}$ cases in a lifetime when applying a $28-\mathrm{d}$ period, instead of a 14-d period, to define new CM cases differed somewhat, but were still statistically significant (1.45 for $1 \mathrm{CM}$ case in early productive life; 1.84 for 2 cases; and 1.64 for 3 cases, compared with no CM cases in early productive life; Table 5). The rate 


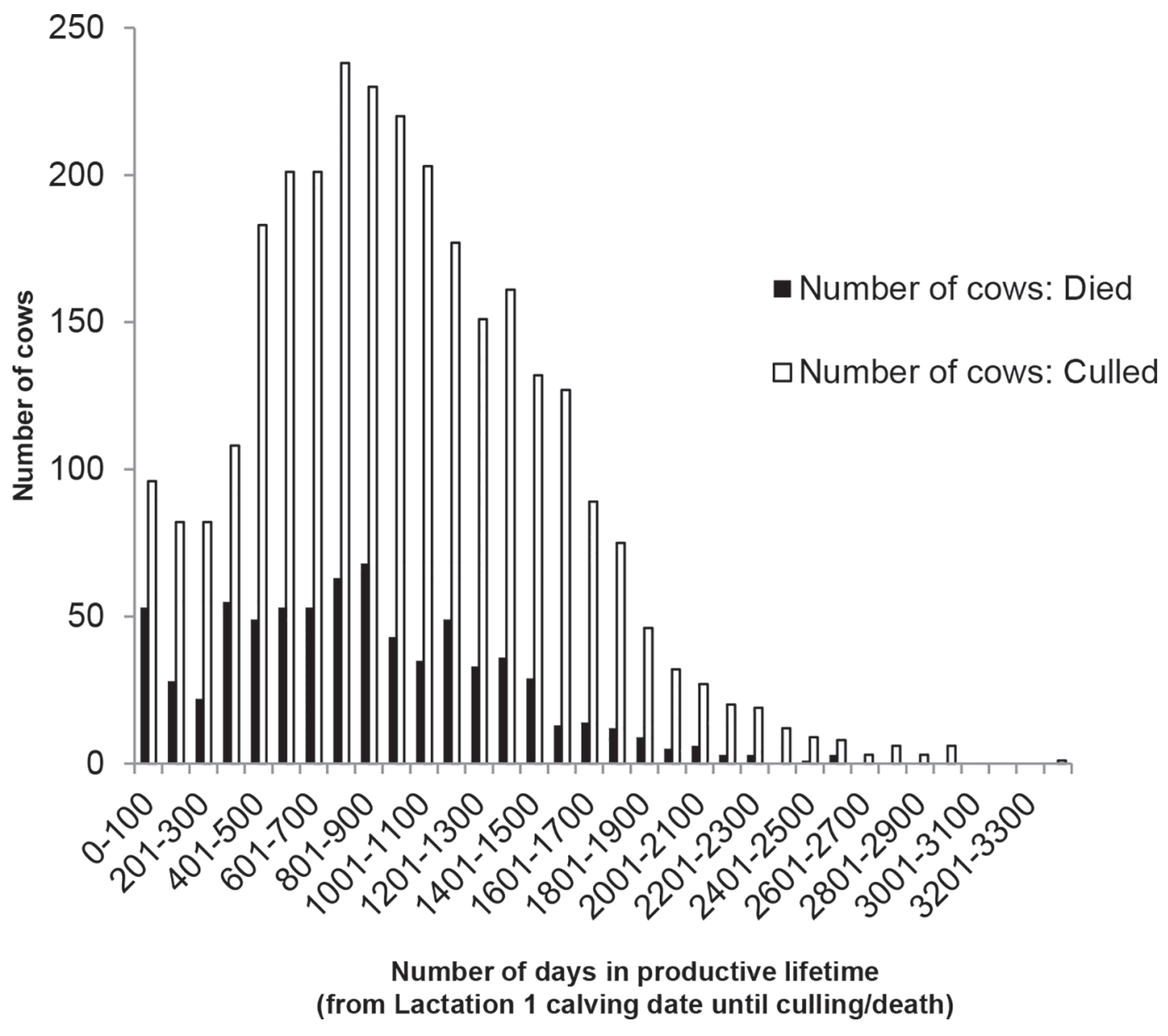

Figure 1. Number of days in productive lifetime (lactation 1 calving date until day culled or died), among 2,948 cows that were culled and 738 cows that died in 5 New York State Holstein dairy herds from 2004 to 2014 . All cows calved for the first time between January 4, 2004, and December 31, 2006.

ratios for other factors in the model did not change meaningfully.

When only cows that had commenced their first lactation in calendar years 2004 to 2006 were included in the model $(\mathrm{n}=3,686)$, the corresponding rate ratios differed from those in the original model (Table 5). Rate ratios were higher for cows with 1 or $2 \mathrm{CM}$ cases in the first $100 \mathrm{~d}$ of lactation 1, but having 3 or more cases in that early time period had no further effect on rate of total number of $\mathrm{CM}$ cases in lifetime. This was the case regardless of whether a 14 - or 28-d period was used to define new CM cases. Estimates did not change meaningfully when the cow's total lifetime milk production was included in the model.

Regarding goodness of fit of the original estimated model (14-d period to define new CM cases; full data set), the Pearson chi-squared was 25,045, with 14,427 df, so the Pearson chi-squared/degrees of freedom was 1.74. For the model incorporating a 28 -d period for definition of new CM cases, the Pearson chi-squared/ degrees of freedom was 1.67. For the other alternative models in Table 5, the Pearson chi-squared/degrees of freedom ranged from 1.73 to 1.82 . These values indicate some evidence of overdispersion. This was assessed by adding the random_residual statement to PROC GLIMMIX for each model; the parameter estimates did not change, and their standard errors were only slightly larger. Because the point estimates of overdispersion are small and relatively little effect on the size of the standard error may be expected, no further adjustments were made to parameters or standard errors of parameters.

\section{Objective 2}

Descriptive Findings. The full data set of 24,831 cows, both alive and culled or dead, was used; Table 3 shows the distribution of case numbers. Approximately 


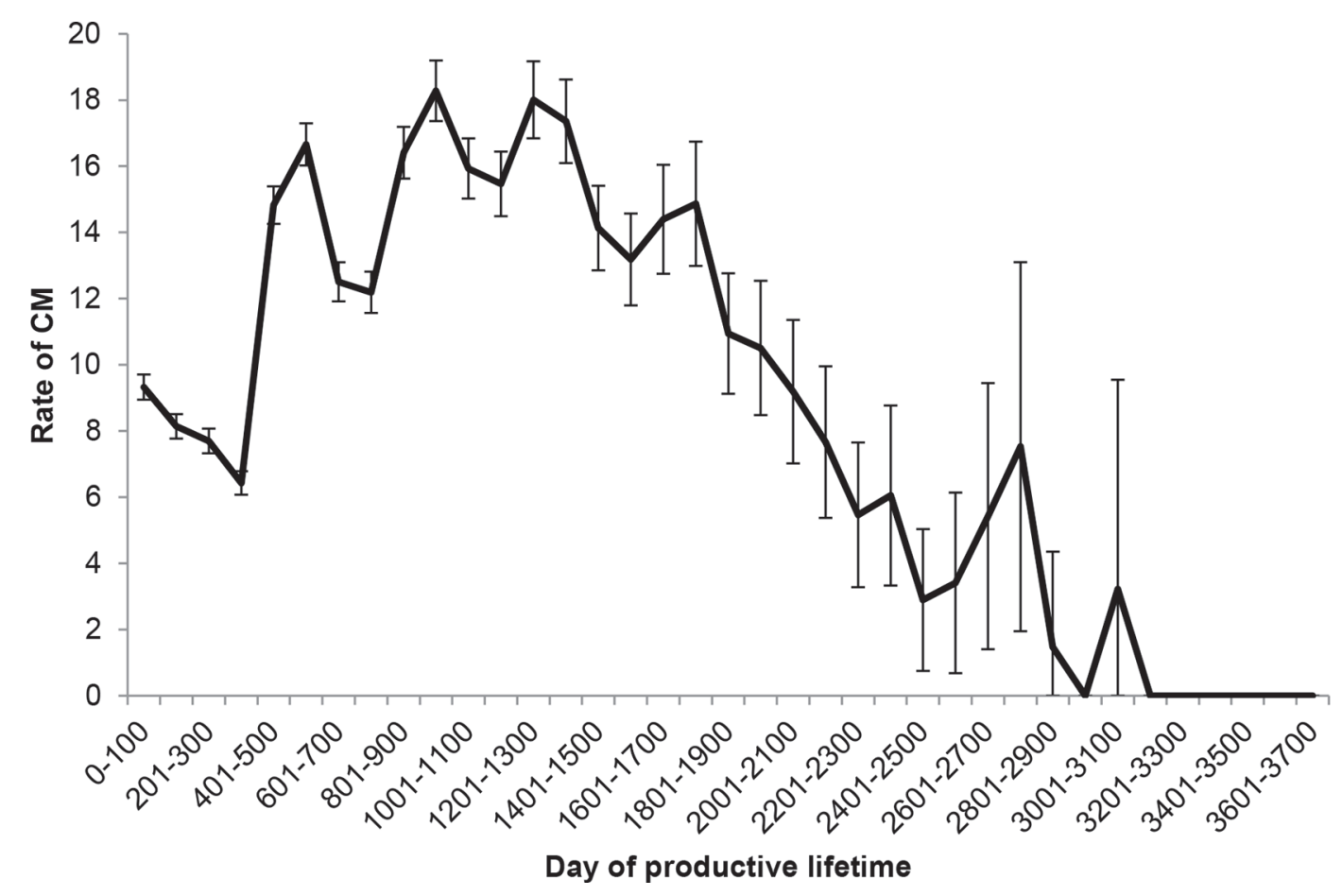

Figure 2. Rate of clinical mastitis (CM; number of CM cases per 10,000 cow-days at risk) and 95\% CI versus day of productive lifetime [beginning at lactation 1 calving date and ending at culling, death, or end of study (4 February 2014), including dry periods between lactations] in 24,831 cows in 5 New York State Holstein dairy herds, followed from 2004 to 2014.

$8 \%$ of all cows followed from January 2004 through February 2014 had at least 1 CM case in the first 100 $\mathrm{d}$ of lactation 1. Over their entire lifetime, cows experienced between 0 and $25 \mathrm{CM}$ cases (Table 6).

The mean length of productive lifetime was $774 \mathrm{~d}$ $(2.1 \mathrm{yr})$; the median was $674 \mathrm{~d}(1.8 \mathrm{yr})$. Productive lifetime ranged from 0 to $3,652 \mathrm{~d}$ ( 0 to $10 \mathrm{yr}$ ). These values included the dry period(s) between lactations (usually approximately $60 \mathrm{~d}$ ).

Effects of CM Cases on Length of Productive Lifetime. Table 7 presents results from a Cox proportional hazards model estimating the effect of number of CM cases in the first $100 \mathrm{~d}$ of lactation 1 on the length of productive lifetime (original model). For each additional CM case occurring in the first $100 \mathrm{~d}$ of lactation 1, the hazard rate of culling increased by $34 \%(P<$ 0.0001). That is, for each additional CM case occurring in the first $100 \mathrm{~d}$ of lactation 1, a cow was 1.34 times more likely to be culled.

In the data set incorporating a 28 -d period for definition of new CM cases, for each additional CM case in early productive life the hazard rate of culling increased by $35 \%(P<0.0001)$. This was nearly identical to the $34 \%$ increase in the original model.

In the data set including only cows whose first lactations commenced in 2004 to 2006 ( $\mathrm{n}=3,798)$, the hazard rate of culling increased by $38 \%(P<0.0001)$ when a 14-d period defining new CM cases was used, and by $39 \%(P<0.0001)$ when a 28 -d period was used. These values were slightly higher than the $34 \%$ increase seen in the original model.

The $-2 \times \log$-likelihood value of the original model without any covariates was $204,585.46$. With the covariate, the $-2 \times \log$-likelihood value was $204,440.28$, so the likelihood ratio chi-square was 145.18 (on $1 \mathrm{df}$; $P<0.0001$ ), indicating a significant improvement with the chosen covariate. For the model incorporating a 28-d period for definition of new CM cases, these values were nearly identical. For the model with a 14-d period for definition of new cases in cows whose first lactation commenced in 2004-2006, the $-2 \times$ log-likelihood value of the model without covariates was 41,744.5. With the covariate, it was $41,712.0$, so the likelihood ratio chi-square was 32.5 (on $1 \mathrm{df} ; P<0.0001$ ). These values were nearly identical when a 28 -d period was used to define new CM cases.

The effects of the number of CM cases in the first $100 \mathrm{~d}$ of lactation 1 on the hazard rate of culling were lower when the cow's total lifetime milk production was included in the model. In the original model this hazard rate of culling increased by only $15 \%(P<0.0001)$, whereas in the model including only cows that commenced their first lactations in 2004 to 2006 it was not significant. 
EARLY MASTITIS, FUTURE MASTITIS, AND HERDLIFE
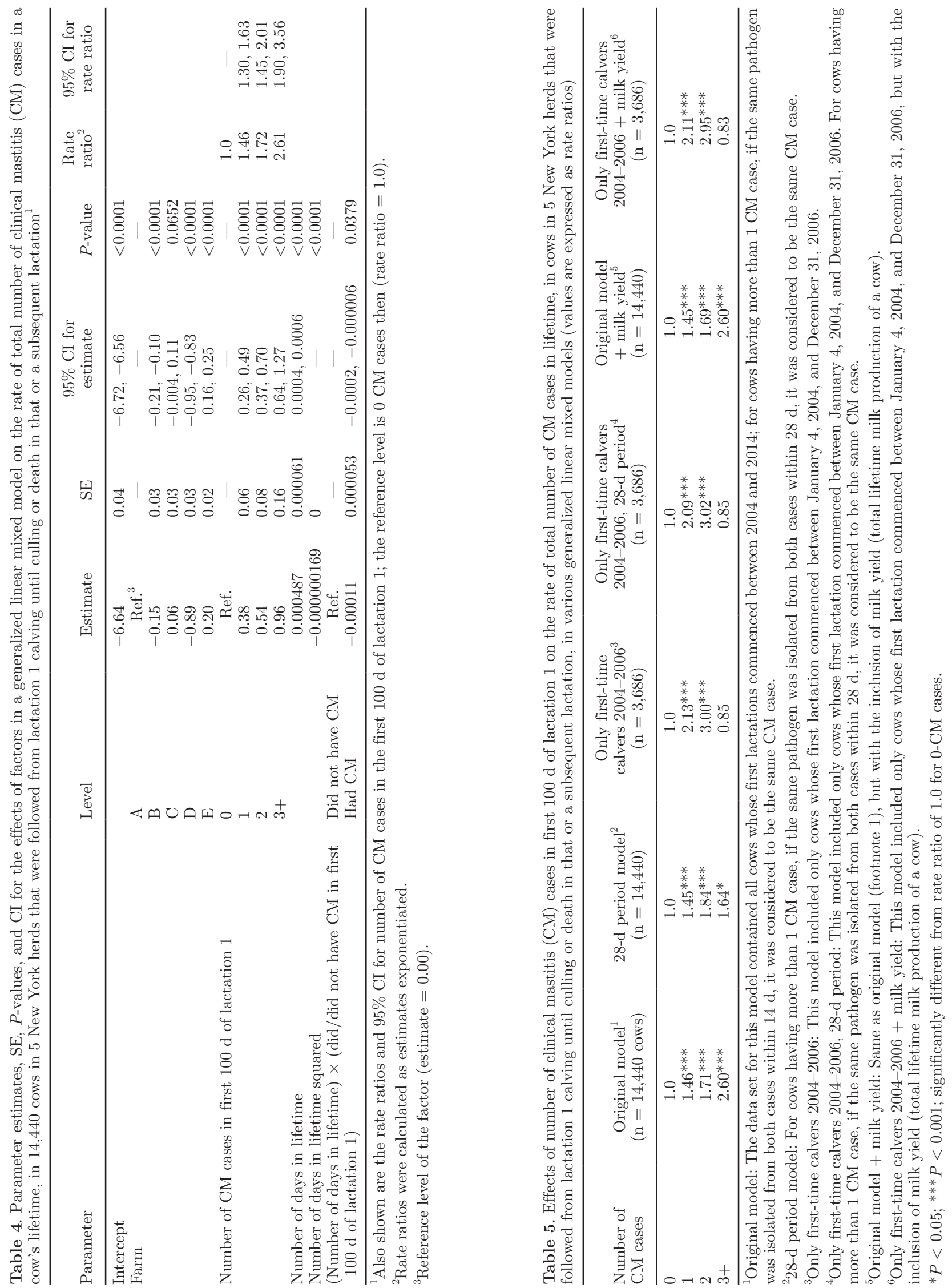
Table 6. Total number of clinical mastitis (CM) cases in lifetime among 24,831 cows followed from January 2004 until February 2014 in 5 New York State Holstein dairy herds

\begin{tabular}{lc}
\hline $\begin{array}{l}\text { Number of CM } \\
\text { cases in lifetime }\end{array}$ & Number of cows $(\%)$ \\
\hline 0 & $13,967(56.2)$ \\
1 & $5,185(20.9)$ \\
2 & $2,529(10.2)$ \\
3 & $1,306(5.3)$ \\
4 & $708(2.9)$ \\
5 & $429(1.7)$ \\
6 & $246(1.0)$ \\
7 & $158(0.6)$ \\
8 & $99(0.4)$ \\
9 & $61(0.2)$ \\
10 & $44(0.2)$ \\
11 & $37(0.1)$ \\
12 & $25(0.1)$ \\
13 & $11(0.04)$ \\
14 & $10(0.04)$ \\
15 & $4(0.02)$ \\
16 & $5(0.02)$ \\
17 & $2(0.01)$ \\
18 & $0(0.0)$ \\
20 & $1(0.004)$ \\
21 & $0(0.0)$ \\
22 & $1(0.004)$ \\
23 & $1(0.004)$ \\
24 & $1(0.004)$ \\
25 & $0(0.0)$ \\
\hline
\end{tabular}

Figure 3 shows the survival curves for cows having 0 , $1,2,3$, or $4 \mathrm{CM}$ cases in the first $100 \mathrm{~d}$ of lactation 1 . With each successive case in that time interval, a cow's long-term survival decreased, although at some time points the curves crossed. Median survival of cows with no $\mathrm{CM}$ in that interval was approximately $1,100 \mathrm{~d}$; only about $15 \%$ of cows with $4 \mathrm{CM}$ cases in that interval had such a long lifetime.

Figure 4 shows survival curves for each cohort of cows based on the year of their first lactation. Cows calving for the first time in 2014 are not included in these curves, as none of them were culled or died before or on the end-of-study date (February 4, 2014). As one would expect, survival curves for cows in earlier cohorts had longer tails, as they had more opportunity to achieve longer lifetimes.

\section{DISCUSSION}

The rate of CM was high until approximately 1,500 d of productive lifetime, when it began to decline (Figure 2). The increase after lactation 1 (i.e., after approximately $400 \mathrm{~d}$ ) may indicate the amplified susceptibility of cows to mastitis with increasing age. Most observational studies show that cows have an increased incidence of $\mathrm{CM}$ with increasing age (Barkema et al., 1998; Hertl et al., 2014b). The drop in lifetime rate of $\mathrm{CM}$ at long productive lifetimes may be associated with positive selection of cows with better health (i.e., less predisposition to CM and other disorders, in long-lived, highly productive cows); therefore, we included the quadratic term (lifetime days squared) in the model. The peak of the incidence was at approximately 1,000 d $(2.7 \mathrm{yr})$ in the milking herd. Only a small portion of the cows will remain in the herd after reaching this point. These long-term survivors would appear to have other characteristics in their favor (e.g., higher milk production or better reproductive capabilities) despite their high but decreasing rates of CM.

Our estimates show that the more CM cases a cow experienced in her first $100 \mathrm{~d}$ of lactation 1, the more $\mathrm{CM}$ cases she was likely to experience in the future. We noted a linear increase in the lifetime rate of future CM with every additional case in the first $100 \mathrm{~d}$. In contrast, but focusing on a shorter time period, Piepers et al. (2010) found that Belgian first-lactation cows with IMI due to CNS in the first week of lactation were less likely to contract CM later in lactation than were first-lactation cows not experiencing an IMI in early lactation. This is perhaps due to CNS having a protective effect against CM due to other, more virulent pathogens, or the different time periods studied. Earlier, Lam et al. (1997) also postulated a protective effect of minor pathogens against subsequent infections in dairy cows due to major pathogens. In particular, in quarters having CM due to Corynebacterium bovis, a minor pathogen, and in quarters with $\mathrm{CM}$ due to both C. bovis and coagulase-negative Micrococcaceae, also a minor pathogen, the rate of infection with major pathogens was lower. These observed effects may be pathogen-dependent.

Table 7. Parameter estimate. SE, hazard ratio, and 95\% confidence limits for hazard ratio in a Cox proportional hazards model for the effect of number of clinical mastitis (CM) cases in the first $100 \mathrm{~d}$ of lactation 1 on the length of productive lifetime in 24,831 cows in 5 New York State herds followed from lactation 1 calving until culling or death or end of study ${ }^{1}$

\begin{tabular}{lcccc}
\hline Parameter & Estimate & SE & Hazard ratio & $\begin{array}{c}95 \% \text { Confidence limits } \\
\text { for hazard ratio }\end{array}$ \\
\hline Number of CM cases in first 100 d of lactation 1 & $0.29 * * *$ & 0.02 & 1.34 & $1.28,1.40$ \\
\hline $\begin{array}{l}{ }^{1} \text { Data collected from January } 2004 \text { until February } 2014 \text { (end-of-study date: February 4, 2014). } \\
* * * P<0.001 .\end{array}$
\end{tabular}




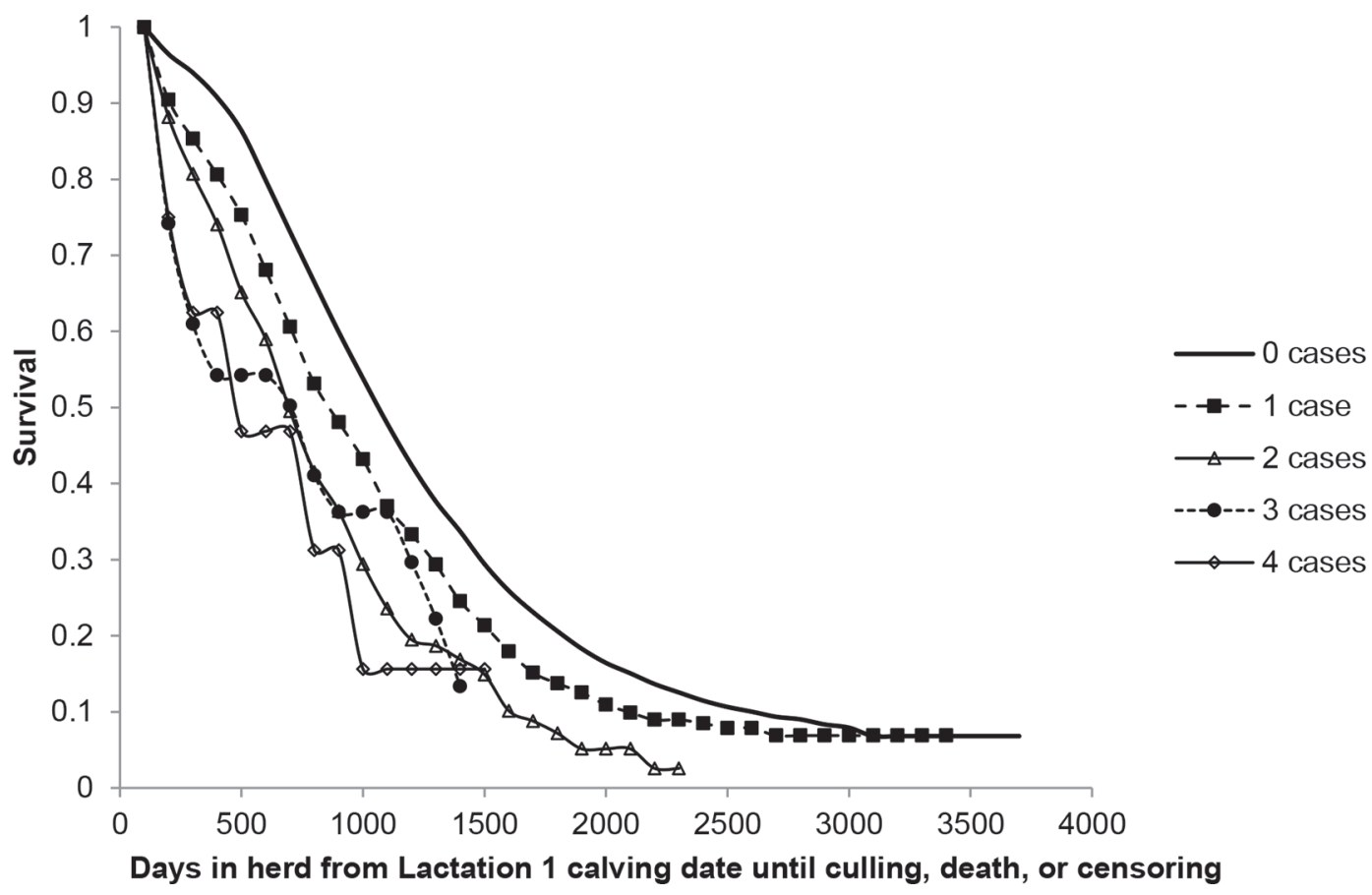

Figure 3. Effect of number of clinical mastitis cases occurring in first $100 \mathrm{~d}$ of lactation 1 on survival in 24,831 cows in 5 New York State Holstein dairy herds.

It is likely that both direct effects and other factors (e.g., genetics, management) are associated with CM in both the first $100 \mathrm{~d}$ of lactation 1 and after that, but we were unable to separate these components. The regression coefficients in the models therefore estimate a combination of both direct effects of $\mathrm{CM}$ in the first

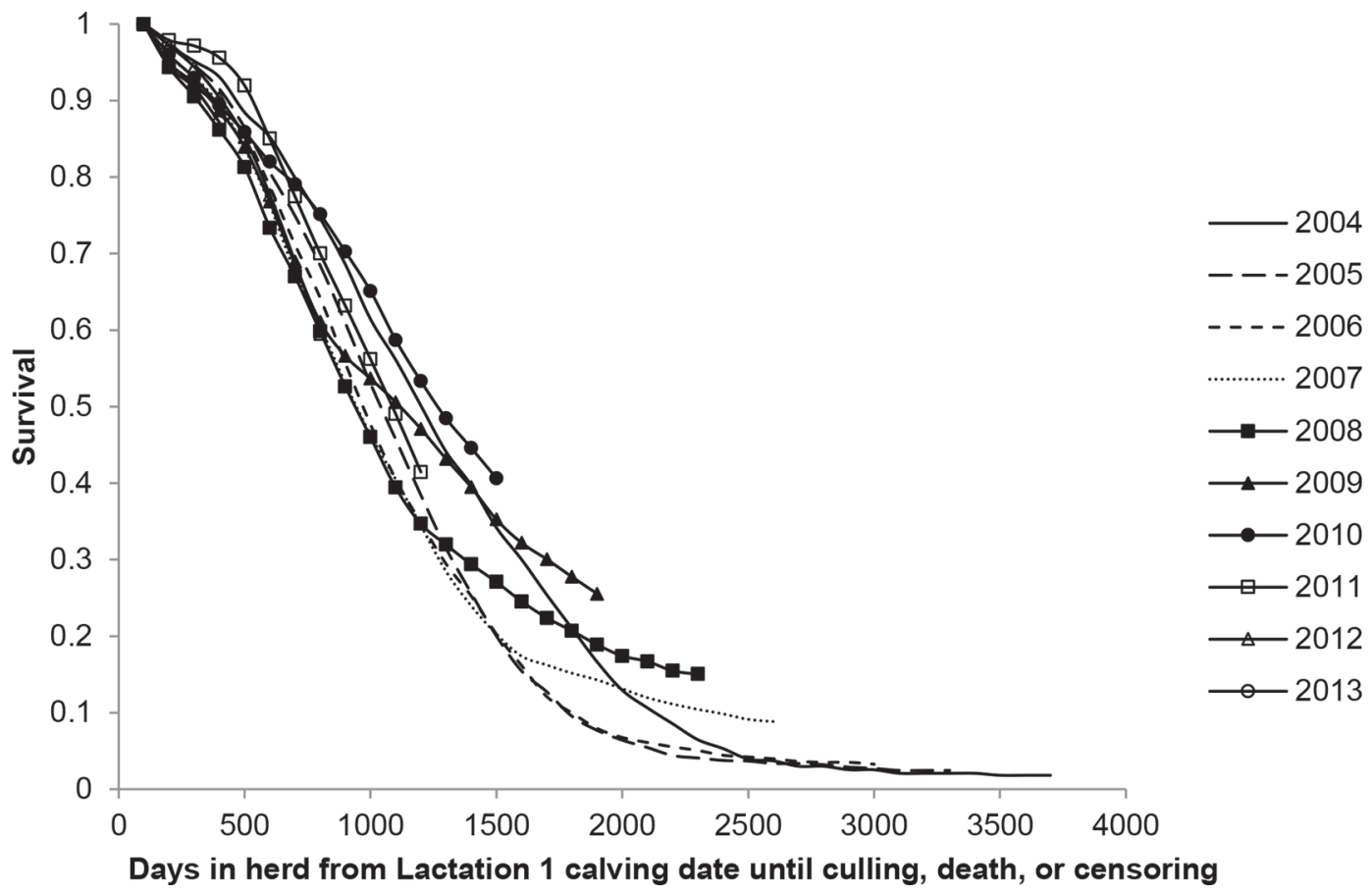

Figure 4. Survival curves for 24,470 cows in 5 New York State Holstein dairy herds, stratified by year of first lactation (2004-2013). A total of 361 (24,831 cows in full data set minus 24,470 cows represented in this figure) cows had their first lactation in 2014; they were not included in this figure, as none of them died or were culled before the end-of-study date (February 4, 2014). 
$100 \mathrm{~d}$ of lactation 1 and the effects of other factors related to $\mathrm{CM}$ in both early life and later in life.

The observed association in our model is then likely to be a combination of direct effects and unmeasured indirect effects. Indirect effects would include a higher genetic susceptibility to $\mathrm{CM}$, so that cows experience more cases in the first $100 \mathrm{~d}$, and the increased genetic susceptibility would also lead to more cases later in life. If the observed relationship was due entirely to the indirect effects, reducing CM incidence in the first 100 $\mathrm{d}$ of lactation 1 through better mastitis-control procedures in this time period would have no effect on CM incidence after the first $100 \mathrm{~d}$ of lactation 1 . The direct effects would indicate that when CM incidence can be reduced in the first $100 \mathrm{~d}$ of productive lifetime (e.g., through better mastitis control procedures in this time period), then the lifetime rate of $\mathrm{CM}$ and the lifetime hazard of culling would decrease. The biology behind such direct effects may be hypothesized to consist of infections in the first $100 \mathrm{~d}$ of lactation 1 that persist in the udder and cause additional CM cases later on. Another biological mechanism may be that infections and the subsequent inflammation in the first $100 \mathrm{~d}$ of productive lifetime cause damage to the udder, resulting in a predisposition to additional $\mathrm{CM}$ cases after d 100. Long-term follow-up studies may be able to somewhat distinguish between these 2 explanations, and long-term IMI across a dry period with antibiotic dry cow therapy are likely quite rare. For both indirect and direct effects, a policy decision of the farmer to cull animals based on (very) high CM incidence in early life would result in fewer cases of CM in the herd of cows. Of course, the economics of such culling policies would need to be studied in much more detail.

We fitted several alternative models (Table 5). In the original model, we used a 14-d period to define new cases. In an alternative model, we extended this period to $28 \mathrm{~d}$, as a case occurring with the same pathogen even after $14 \mathrm{~d}$ but less than $28 \mathrm{~d}$ might still be the same case. The effects of 1 or $2 \mathrm{CM}$ cases occurring early in productive life on the rate of total number of $\mathrm{CM}$ cases in lifetime were similar regardless of whether the period defining new cases was 14 or 28 d. In contrast, the effect of 3 or more CM cases in early productive life was lower, although still significant, when a 28 -d period was used.

When only cows commencing their first lactation in 2004 to 2006 were included in the model, the effects of $\mathrm{CM}$ cases occurring in the first $100 \mathrm{~d}$ of lactation 1 differed markedly from the original model, which included all cows commencing their first lactation in 2004 to 2014 . The effects of 1 or $2 \mathrm{CM}$ cases in early productive life had a larger effect on the rate of total number of $\mathrm{CM}$ cases in lifetime in cows first calving in 2004 to 2006 than in the full data set. The effect of 3 or more CM cases in early productive life was not significant, likely due to very small numbers resulting in a less stable effect estimate.

Addition of the total lifetime milk production of a cow to the models did not meaningfully change the estimates of the effects of number of CM cases in early productive life. Furthermore, milk yield is probably both a cause and effect of CM. The causality of any association between CM and milk yield is complex; milk yield before a case of CM in early life may have a confounding effect on lifetime CM occurrence or on the risk of culling (which may be removed by including preCM milk production in the model), but $\mathrm{CM}$ also has causal effects on reducing milk yield (which should not be removed by adjustment). These 2 competing effects (both high and low milk production are associated with $\mathrm{CM})$ cannot be disentangled from lifetime milk production, so this production variable was not included in the original final model.

As shown in Table 7, for each additional CM case that a cow had in the first $100 \mathrm{~d}$ of her first lactation, her hazard rate of culling increased by $34 \%$, so that cows with more CM cases in early productive life were culled at a higher rate than were cows with fewer CM cases in early productive life. This can also be seen graphically in Figure 3, in which the lowest proportion of cows surviving to each time point were those with 3 or $4 \mathrm{CM}$ cases in early productive life. The hazard rate of culling was only slightly higher (ranging between 35 and $39 \%$ ) when fitting variations of the original model (as described in Table 5).

When lifetime milk production was added to these models, however, the hazard rate of culling increased by a smaller amount ( $15 \%$ in the original model, and not at all in the model for cows commencing their first lactations in 2004-2006) for each additional CM case in early productive life. It is likely that culling is a multifactorial decision. Both CM and decreased milk yield play a role in culling, along with other unmeasurable factors, such as cow temperament. As stated above, milk yield is probably both a cause and effect of CM. Recent and current milk production is a chief determinant of culling. Therefore, the causality of associations among CM, milk yield, and culling are complex (Gröhn et al., 1998). The confounding effects of milk yield (i.e., effects of pre-CM milk yield on risk of both CM and culling) should be removed by adjustment. Effects of CM on milk yield, which in turn affect risk of culling, should not be removed by adjustment when assessing the effects of CM. This cannot be disentangled using lifetime milk production. It appears that the lifetime drop in milk yield is then an intermediate variable between $\mathrm{CM}$ and the event of culling. 
The mean length of productive life in the study herds was approximately $2 \mathrm{yr}$; this represented observed data and included censored cows. In these herds the median life expectancy for a cow that has just calved was calculated to be approximately $1,100 \mathrm{~d}$, or $3 \mathrm{yr}$ (data not shown), which is the true median lifetime in cows that have had sufficient time to be observed (e.g., calved in 2004). This latter value of $3 \mathrm{yr}$ agrees with estimates from the literature (Knaus, 2009; Gaillard et al., 2016).

Bar et al. (2008b), in dynamic programming of generic CM using the initial years of data of the current study, determined that an average cow produced $\$ 426$ net return per year. They also determined that the cost per case of generic CM managing the cow optimally was $\$ 179$ per case and was similar regardless of whether it was the first, second, or third case in a lactation, although the cost was significantly higher if the CM occurred early in a lactation. They found that, for an average yield cow, CM $61 \mathrm{~d}$ after calving incurred a cost of $\$ 355$. Thus, CM in the first $100 \mathrm{~d}$ incurs a very high initial cost and subsequent cases add to this cost. More than 2 cases per lactation may exhaust all net return from the average cow. A dynamic programming analysis of CM in the first $100 \mathrm{~d}$ of the first lactation would determine these exact costs, but it appears that they would be significant. Our data were generated from well-managed farms, and the fact that the estimated hazard rate for culling or dying increased by $34 \%$ if CM occurred in the first $100 \mathrm{~d}$ of the first lactation may be because these farmers preferentially culled (after $\mathrm{d}$ 100) cows that had CM in the first $100 \mathrm{~d}$ of productive lifetime. These cows (with early-occurring CM) remaining in the herd had, on average, more CM cases after $\mathrm{d}$ 100 of lactation 1, and perhaps lower subsequent milk production as well.

The herds in our study were all relatively wellmanaged and high-producing, but fairly representative of a large population of US dairy herds in terms of production and health (Caraviello et al., 2006). The main reason for selection of the herds was their reliable and comprehensive recordkeeping, availability of routine culture results, and the willingness of owners and managers to work with our team of researchers. As such, the findings from our study may not extrapolate to other types of farms that may differ in production level, management practices, or other characteristics. Biologically relevant relationships, however, are likely to be of value across the spectrum of herds. It is therefore likely that the pathobiology underlying repeated cases of mastitis will be relevant for other herds as well. Also, as always with observational studies, internal validity (how justifiable a conclusion of causality is, based on how well bias is minimized in the study) is preferred over external validity (the extent to which the study results can be generalized to other settings).

A motivation for our study was to see how CM in early productive life might affect farmers' culling decisions. As stated earlier, we speculated that the farmers preferentially culled (after d 100) cows that had CM in the first $100 \mathrm{~d}$ of lactation 1 because these cows tended to have more $\mathrm{CM}$ cases after that time, and perhaps also had lower milk production; our speculation was validated by the empirical results.

The results of our study establish a relationship between early mastitis occurrence and future cases of mastitis and a related risk of culling. The lifetime rate of CM increased with cow age and, therefore, increases with the number of days that a cow is in the milking herd. Having more CM cases in early life also increases the risk of culling, which for these identified high-risk cows reduced the total days at risk.

One problem with such studies is that management decisions, which may be difficult or impossible to measure accurately, have a large effect on culling, beyond the pure economic effect provided by optimization models. Cow temperament, which may have no association with milk production, CM (or other diseases), or reproduction, may be a deciding factor in a farmer's culling decision. For example, a kicker may be culled even if she has fairly high milk yield and is healthy (and thus economically valuable). Concrete information on such factors is not readily available or reliable; they relate more to a farmer's mindset. That is, a healthy cow that is a kicker might be culled but a CM cow with a nice personality might be kept. Consequently, the model (in which we were unable to incorporate such information) may be overestimating the true (possible) effect of CM on culling.

Nevertheless, the data presented in the current study may be used by farmers (in similar herds) in making culling decisions in their day-to-day management, assuming that the farmers in our study herds made rational culling decisions based upon economics and other factors, including the incidence of CM occurring in the first $100 \mathrm{~d}$ of lactation 1 . It may be that " 3 strikes and you are out" may not only be appropriate for US baseball, but also cows experiencing 3 or more mastitis cases during their first $100 \mathrm{~d}$ of productive life. Although genetic markers for SCC exist to assist farmers in making breeding or culling decisions, cows with several cases of CM early in their lifetime are likely not cows that the farmer wants to breed for replacement. At the very least the nonindependence of lifetime mastitis events should be taken into account for decision making. Such animals are at increased risk throughout their lifetime for further CM cases and also at increased 
risk of culling. Breeding these animals to low-cost semen or to semen from bulls with predominantly beef value may be more economically appropriate. Similarly, when making culling decisions with regard to udder health on the farm, farmers should give high weight to the udder health data of the first $100 \mathrm{~d}$ in lactation. As shown in our data, this information on the first 100 $\mathrm{d}$ in lactation is of predictive value of future health performance. Assuming that the observed relationship was due entirely to the direct effect of $\mathrm{CM}$, for each case of CM in early life a cow's life expectancy dropped by $200 \mathrm{~d}$, which represents two-thirds of a typical 305-d lactation, an extensive amount of production lost to a common disease in the dairy industry.

The information on effects of early-occurring $\mathrm{CM}$ on risk of future cases and on length of productive lifetime gained from our study provides insight into the possible mechanisms underlying the observed phenomenon that a case of $\mathrm{CM}$ results in a higher risk of subsequent cases. Our data would indicate that this increased risk is not just present in the same lactation but also across lactations. This long time period makes it unlikely that the observed relationship is only due to the chosen definition (interval of $14 \mathrm{~d}$ between cases) or even only due to persistence of infection. Persistence of an IMI is less likely, but not impossible, when a dry period with an antibiotic treatment occurs between the initial cases and the subsequent cases. From the data in our study it appears to be more likely that either an inherent higher susceptibility to $\mathrm{CM}$ or an acquired increased susceptibility to CM may explain the observed CM patterns. Such findings can only be obtained in observational studies with very long follow-up periods (10 yr in the present study).

Our findings can also be used to construct more informative cow replacement decision rules using dynamic programming or other replacement algorithms. Previously, little information was available on the incidence of future mastitis cases conditional on the number of early mastitis cases.

Given our findings that CM cases occurring in early productive life appear to be predictive of future CM cases and of shortened herdlife, the suggestion of Compton et al. (2007) that different means of mastitis prevention and control should be used in heifers than are used in older cows is prudent. Although their study was in pasture-grazed peripartum heifers in New Zealand, which are managed quite differently from our New York study herds, the idea of revisiting mastitis control programs in heifers and first-lactation cows may be appropriate.

Management decisions apart, we believe that the analyses conducted in our study are by themselves a step forward in understanding of bovine mastitis. Our objective was to evaluate whether CM cases in early productive life would be predictive for future cases and potentially for the rate of survival in the herd. The value of this is 3 fold. First, it provides a window of knowledge for the farmer with regard to the likelihood of further CM cases in particular high-risk animals and the management of such high-risk animals. Second, given that we observed a predictive value of early-life CM cases for future CM cases, it provides an opportunity to improve the genetic CM susceptibility of first-lactation animals (and older animals) so that there will ultimately be fewer lifetime CM cases. Finally, the observed relationship between $\mathrm{CM}$ in early life and lifetime risk of CM provides further evidence that either inherent or acquired susceptibility to CM plays an important role. Further research into both of these mechanisms will be important for a true reduction of CM in dairy cows over time. Particularly, the potential acquired susceptibility after an initial case of CM may provide opportunities in developing interventions, such as better treatments or treatments aimed at restoring or improving the immune function of the mammary gland.

In future research, it would be interesting to replicate this analysis for individual mastitis pathogens. For example, do cases of Escherichia coli early in productive life have a larger effect on a cow's future than cases of Streptococcus spp.? Previous research by our group (Hertl et al., 2014a,b) found that dissimilar pathogens have different effects on milk production and conception, so these various pathogens may also differ in their effects on future lifetime rate of $\mathrm{CM}$ and total productive lifetime.

\section{CONCLUSIONS}

This study estimated the direct effects of CM occurring early in productive life (first $100 \mathrm{~d}$ of lactation 1) on the future lifetime rate of $\mathrm{CM}$ occurrence and the length of the total productive lifetime of Holstein cows in 5 New York State dairy farms. Assuming that the observed relationship was due entirely to the direct effect of CM cases occurring early in productive life, $\mathrm{CM}$ cases occurring then increased the lifetime rate of contracting subsequent CM cases: the more $\mathrm{CM}$ cases a cow had early on in her life, the higher the rate of CM she would experience over her lifetime. Also, assuming that the observed relationship was due entirely to the direct effect of CM cases occurring early in productive life, such cases shortened total productive lifetime. These findings may help provide insight into management of dairy cows with repeated CM cases early in productive life. 


\section{ACKNOWLEDGMENTS}

The USDA (CSREES) Award No. 2010-65119-20478 provided funding for this study. The authors thank owners and personnel from the 5 dairies, and the personnel of the Ithaca, Canton, and Geneseo Regional Laboratories, Quality Milk Production Services, for their valuable cooperation.

\section{REFERENCES}

Bar, D., Y. T. Gröhn, G. Bennett, R. N. González, J. A. Hertl, H. F. Schulte, L. W. Tauer, F. L. Welcome, and Y. H. Schukken. 2008a. Effects of repeated episodes of generic clinical mastitis on mortality and culling in dairy cows. J. Dairy Sci. 91:2196-2204.

Bar, D., L. W. Tauer, G. Bennett, R. N. González, J. A. Hertl, Y. H. Schukken, H. F. Schulte, F. L. Welcome, and Y. T. Gröhn. 2008b. The cost of generic clinical mastitis in dairy cows as estimated by using dynamic programming. J. Dairy Sci. 91:2205-2214.

Barkema, H. W., Y. H. Schukken, T. J. Lam, M. L. Beiboer, H. Wilmink, G. Benedictus, and A. Brand. 1998. Incidence of clinical mastitis in dairy herds grouped in three categories by bulk milk somatic cell counts. J. Dairy Sci. 81:411-419.

Beaudeau, F., V. Ducrocq, C. Fourichon, and H. Seegers. 1995. Effect of disease on length of productive life of French Holstein dairy cows assessed by survival analysis. J. Dairy Sci. 78:103-117.

Caraviello, D. Z., K. A. Weigel, P. M. Fricke, M. C. Wiltbank, M. J. Florent, N. B. Cook, K. V. Nordlund, N. R. Zwald, and C. L. Rawson. 2006. Survey of management practices on reproductive performance of dairy cattle on large US commercial farms. J. Dairy Sci. 89:4723-4735.

Cha, E., J. A. Hertl, Y. H. Schukken, L. W. Tauer, F. L. Welcome, and Y. T. Gröhn. 2013. The effect of repeated episodes of bacteriaspecific clinical mastitis on mortality and culling in Holstein dairy cows. J. Dairy Sci. 96:4993-5007.

Cha, E., J. A. Hertl, Y. H. Schukken, L. W. Tauer, F. L. Welcome, and Y. T. Gröhn. 2016. Evidence of no protection for a recurrent case of pathogen specific clinical mastitis from a previous case. J. Dairy Res. 83:72-80.

Compton, C. W. R., C. Heuer, K. Parker, and S. McDougall. 2007. Epidemiology of mastitis in pasture-grazed peripartum dairy heifers and its effects on productivity. J. Dairy Sci. 90:4157-4170.

Faye, B., R. Boulme, F. Lescourret, and J. B. Coulon. 1996. A method for describing disease patterns during the life span of dairy cows. Vet. Res. 27:453-464.

Fitzpatrick, C. E., N. Chapinal, C. S. Petersson-Wolfe, T. J. DeVries, D. F. Kelton, T. F. Duffield, and K. E. Leslie. 2013. The effect of meloxicam on pain sensitivity, rumination time, and clinical signs in dairy cows with endotoxin-induced clinical mastitis. J. Dairy Sci. 96:2847-2856.

Fogsgaard, K. K., T. W. Bennedsgaard, and M. S. Herskin. 2015. Behavioral changes in freestall-housed dairy cows with naturally occurring clinical mastitis. J. Dairy Sci. 98:1730-1738.

Gaillard, C., O. Martin, P. Blavy, N. C. Friggens, J. Sehested, and H. N. Phuong. 2016. Prediction of the lifetime productive and reproductive performance of Holstein cows managed for different lactation durations, using a model of lifetime nutrient partitioning. J. Dairy Sci. 99:9126-9135.

Gröhn, Y. T., S. W. Eicker, V. Ducrocq, and J. A. Hertl. 1998. Effect of diseases on the culling of Holstein dairy cows in New York State. J. Dairy Sci. 81:966-978.
Gröhn, Y. T., D. J. Wilson, R. N. González, J. A. Hertl, H. Schulte, G. Bennett, and Y. H. Schukken. 2004. Effect of pathogen-specific clinical mastitis on milk yield in dairy cows. J. Dairy Sci. 87:3358-3374.

Herath, S., S. T. Lilly, D. P. Fischer, E. J. Williams, H. Dobson, C. E. Bryant, and I. M. Sheldon. 2009. Bacterial lipopolysaccharide induces an endocrine switch from prostaglandin $\mathrm{F}_{2 \alpha}$ to prostaglandin $\mathrm{E}_{2}$ in bovine endometrium. Endocrinology 150:1912-1920.

Heravi Moussavi, A., M. Danesh-Mesgaran, and R. O. Gilbert. 2012. Effect of mastitis during the first lactation on production and reproduction performance of Holstein cows. Trop. Anim. Health Prod. 44:1567-1573.

Hertl, J. A., Y. H. Schukken, F. L. Welcome, L. W. Tauer, and Y. T. Gröhn. 2014a. Pathogen-specific effects on milk yield in repeated clinical mastitis episodes in Holstein dairy cows. J. Dairy Sci. 97:1465-1480.

Hertl, J. A., Y. H. Schukken, F. L. Welcome, L. W. Tauer, and Y. T. Gröhn. 2014b. Effects of pathogen-specific clinical mastitis on probability of conception in Holstein dairy cows. J. Dairy Sci. 97:6942-6954.

Houben, E. H. P., A. A. Dijkhuizen, J. A. M. van Arendonk, and R. B. M. Huirne. 1993. Short- and long-term production losses and repeatability of clinical mastitis in dairy cattle. J. Dairy Sci. $76: 2561-2578$.

Knaus, W. 2009. Dairy cows trapped between performance demands and adaptability. J. Sci. Food Agric. 89:1107-1114.

Kossaibati, M. A., and R. J. Esslemont. 1997. The costs of production diseases in dairy herds in England. Vet. J. 154:41-51.

Lam, T. J., Y. H. Schukken, J. H. van Vliet, F. J. Grommers, M. J. Tielen, and A. Brand. 1997. Effect of natural infection with minor pathogens on susceptibility to natural infection with major pathogens in the bovine mammary gland. Am. J. Vet. Res. 58:17-22.

Moosavi, M., A. Mirzaei, M. Ghavami, and A. Tamadon. 2014. Relationship between season, lactation number and incidence of clinical mastitis in different stages of lactation in a Holstein dairy farm. Vet. Res. Forum 5:13-19.

Neerhof, H. J., P. Madsen, V. P. Ducrocq, A. R. Vollema, J. Jensen, and I. R. Korsgaard. 2000. Relationships between mastitis and functional longevity in Danish Black and White dairy cattle estimated using survival analysis. J. Dairy Sci. 83:1064-1071.

Olde Riekerink, R. G. M., H. W. Barkema, D. F. Kelton, and D. T. Scholl. 2008. Incidence rate of clinical mastitis on Canadian dairy farms. J. Dairy Sci. 91:1366-1377.

Pennsylvania Department of Health. 2017. Confidence intervals for a crude rate. Accessed May 17, 2017. http://www.statistics .health.pa.gov/StatisticalResources/UnderstandingHealthStats/ ToolsoftheTrade/Documents/Confidence_Intervals_for_a_Crude Rate.pdf.

Piepers, S., G. Opsomer, H. W. Barkema, A. de Kruif, and S. De Vliegher. 2010. Heifers infected with coagulase-negative staphylococci in early lactation have fewer cases of clinical mastitis and higher milk production in their first lactation than noninfected heifers. J. Dairy Sci. 93:2014-2024.

Schukken, Y. H., J. Hertl, D. Bar, G. J. Bennett, R. N. González, B. J. Rauch, C. Santisteban, H. F. Schulte, L. Tauer, F. L. Welcome, and Y. T. Gröhn. 2009. Effects of repeated gram-positive and gram-negative clinical mastitis episodes on milk yield loss in Holstein dairy cows. J. Dairy Sci. 92:3091-3105.

Thomsen, P. T., A. M. Kjeldsen, J. T. Sørensen, and H. Houe. 2004. Mortality (including euthanasia) among Danish dairy cows (19902001). Prev. Vet. Med. 62:19-33.

van Soest, F. J. S., I. M. G. A. Santman-Berends, T. J. G. M. Lam, and H. Hogeveen. 2016. Failure and preventive costs of mastitis on Dutch dairy farms. J. Dairy Sci. 99:8365-8374. 